This is the peer reviewed version of the following article: Brown, R. , McQuaid, R. , Raeside, R. , Dutton, M. , Egdell, V. and Canduela, J. (2019), Buying into Capitalism? Employee Ownership in a Disconnected Era. British Journal of Industrial Relations, 57: 62-85, which has been published in final form at https://doi.org/10.1111/bjir.12309. This article may be used for non-commercial purposes in accordance with Wiley Terms and Conditions for self-archiving.

\title{
Buying into Capitalism? Employee Ownership in a Disconnected Era
}

\author{
Ross Brown, University of St Andrews \\ Ronald McQuaid, University of Stirling \\ Robert Raeside, Edinburgh Napier University \\ Matthew Dutton, Edinburgh Napier University \\ Valerie Egdell, Edinburgh Napier University
}

\begin{abstract}
This paper considers whether employee ownership mitigates the negative workplace outcomes identified by the Disconnected Capitalism Thesis (DCT). Drawing on a programme of in-depth interviews with workers and managers in EOBs, the paper reveals how they are partially insulated from the vicissitudes endemic within contemporary capitalism. In contrast to the workplace outcomes envisaged within the DCT, these firms are characterised by strong workforce participation, high levels of employment security, active employee engagement and strong levels of employee creativity. Not only are these features beneficial for productivity and firm performance, they generate a form of "connected" capitalism, partially offsetting wider negative systemic forces at play in the economy.
\end{abstract}

Key Words:

Employee ownership Disconnected Capitalism Job security

Employee Voice Employee Engagement United Kingdom

Word Count: 9995 


\section{Introduction}

"The problem with capitalism is there aren't enough capitalists" (Quote from the Employee Ownership film "We the Owners")

The global financial crisis starting in 2007 instigated a 'fundamental rethink' (Stiglitz, 2015) about the socio-economic relationships in many advanced economies, leading to increased interest in alternatives to investor-owned firms (Blasi et al. 2014). Of particular interest to researchers and policy makers in this regard is employee ownership (Poutsma et al. 2012; Pendleton and Poutsma 2012; Blasi et al. 2016). According to some, this 'atypical' mode of corporate governance is a means of mitigating the inherent inequalities and instabilities endemic within contemporary capitalism (Kruse et al. 2010; Blasi et al. 2014; Kurtulus and Kruse, 2017) ${ }^{1}$.

However, some scholars question the likelihood and sustainability of this kind of 'equitable' outcome within the workplace (Thompson 2003) ${ }^{2}$, especially given the deleterious effects globalisation and financialisation are having across workplaces, most notably chronic job insecurity and employee detachment (McCann 2014; Thompson 2013). The so-called disconnected capitalism thesis (henceforth DCT) conceptualises the systemic forces within

\footnotetext{
${ }^{1}$ Some scholars use terms such as 'shared capitalism' (Kruse et al. 2010), 'broad-based capitalism' (Blasi et al. 2016) or 'responsible enterprise' (Storey and Salaman 2017) to denote these alternative ownership arrangements. ${ }^{2}$ While Thompson does not explicitly pay reference to employee ownership, this is arguably one of the highcommitment work regimes he claims cannot withstand the malign forces embedded within the DCT.
} 
global capitalism which are argued to be fundamentally recasting labour-management relations (Thompson 2003; Dobbins and Dundon 2015). Linking these macro-level changes to upheavals at the micro-level of the firm, Thompson (2003) claims there is a "massive tension" between the types of stability needed to foster high performance in the workplace and the "insecurity inherent in current forms of corporate governance" (p. 365) and that employees are "asked to unconditionally invest more of themselves" while "employer promises are purely conditional" (pp. 364-365).

While the DCT is "theoretically attentive to how workplace processes are linked to macrostructures" (Hauptmeier and Vidal 2014: 22), little attempt has been made to assess its potential implications for workers or workplace relations. This paper examines whether employee owned businesses (EOBs) are able to withstand the destabilising forces conveyed within the DCT. Strictly speaking, as projected within the DCT, EOBs and their employees would seem just as likely to befall the same negative consequences afflicting traditional capitalist organisations. However, this goes against the vast body of literature on employee ownership accumulated over the last three decades indicating that these firms perform differently to more conventionally-structured firms on a number of metrics such as firm survival, job security, levels of employee participation, human capital development and wage levels (Baghdadi et al. 2013; Kramer 2010; Pendleton and Robinson, 2011; O’Boyle et al. 2016; Richter and Schrader 2016); even during recessionary periods (Lampel et al. 2014; Kurtulus and Kruse 2017).

Importantly, however, a key omission within this literature is an in-depth examination of the workplace factors underpinning this organisational resilience despite the dysfunctional aspects 
of contemporary capitalism. This paper seeks to fill this gap. Therefore, the paper makes a novel theoretically-informed contribution to the employee ownership literature by examining the nature of workplace conditions and management-labour relations within employee-owned firms during an era of intense economic and labour market turbulence following the financial crisis. The paper's overriding research question is: can employee ownership insulate firms from the dysfunctional elements of contemporary capitalism depicted by the disconnected capitalism thesis?

The paper reports the findings of an in-depth empirical study of firms transitioning into employee ownership in Scottish firms during the post financial crisis period ${ }^{3}$. Scotland provides an interesting empirical backdrop to this research as successive Scottish and UK governments have extolled "the virtues of the John Lewis economy" (Wilkinson et al. 2014: 739)", with employee ownership attracting more attention than ever before (Pendleton 2011). Somewhat paradoxically, renewed interest in the 'participative infrastructure' of firms (Wright and Snell 1998) has been particularly strong in liberal market economies such as the UK and the USA (Croucher et al. 2010). Indeed, an estimated one-fifth of all private sector employment is under employee ownership in the USA (Kurtulus and Kruse 2017) while in the UK EOBs contribute $£ 30$ bn to the country's GDP and are growing at a rate of nearly $10 \%$ per annum ${ }^{5}$. Examining employee ownership in this context is therefore highly salient owing to its important societal and policy relevance.

\footnotetext{
${ }^{3}$ This paper focuses solely on EOBs where employees, either directly or through an employee benefits trust, hold the majority of shares.

4 John Lewis is a UK major employee-owned retailer employing 90,000 "partners" (Storey and Salaman 2017).

${ }^{5}$ Data from the Employee Ownership Association website: http://employeeownership.co.uk/
} 
The remainder of the paper considers relevant literature, followed by an outline of the methods used and the characteristics of the interviewed firms. Next the findings are presented, before a discussion and conclusions are drawn.

\section{Literature Review}

\subsection{The Disconnected Capitalism Thesis}

Thompson (2013) acknowledges that the DCT is not a comprehensive theory but rather a wideranging conceptual umbrella encapsulating the changing nature of institutional inter-relations and dynamics, inherent within contemporary capitalism, which are marked by "increased and disruptive tensions between what capital is seeking from employees in the labour process and what it finds necessary to enforce in the realm of employment relations" (Thompson, 2003: 364). Three core interlinked factors are claimed to underpin the transition to disconnected capitalism: the "disappearance of the old economy" characterised by large-scale Fordist firms supplanted by "knowledge-based labour in a largely service context"; a shift to "internalized commitment and self-discipline among employees"; and the substitution of hierarchy by networks "in which private capital is the only significant actor, with the state and labour marginalized" (Thompson, 2003: 359) ${ }^{6}$. Cumulatively these forces coalesce to produce a powerful 'cocktail' where the "structural tendencies, driven by developments in capital markets....are exacerbating disunity between these different domains" (Thompson 2003: 360). For example, Thompson (2013) notes how target setting for cost savings and performance

\footnotetext{
${ }^{6}$ The terms "Fordism" and "Fordist" are used interchangeably in this paper to denote the diverse macroeconomic regime linking mass production and mass consumption, labour processes linked to Taylorism and associated welfare policies commonly associated with regulation theorists (Jessop 1995).
} 
measures tighten control and reduce security for large sections of the workforce. Furthermore, global finance has "ceased simply to assist the running and operation of the real economy...but rather has come to dominate, even displace, the latter" (Christopherson 2013: 352).

The DCT suggests that many of the macro-level structural changes associated with this emerging global neoliberal economic paradigm are likely to lead to erosions of workplace conditions, reducing employment security and conditions within the workplace (Thompson 2013). So what are key micro-foundations of the DCT? Crucially, within this environment one could expect recurring features running across profit-driven organisations to include increasing levels of employment insecurity, increased casualization of employment, downward pressure on pay and conditions, diminished employee autonomy/creativity and increased use of outsourcing to lower cost non-unionised environments. For example, recent survey data reveals that approximately $20 \%$ of workers in the UK are not in regular full-time employment and that performance monitoring for non-managerial staff rose from $43 \%$ in 2004 to $70 \%$ in 2011 (Findlay and Thompson, 2017). Furthermore, the 2016 Labour Force Survey shows that 905,000 people (or $2.8 \%$ of the UK workforce) in the UK were on zero-hour contracts, a rise of more than 100,000 since 2015 (ONS, 2017). Consequently, there are "sharp declines in employee commitment and morale related to factors such as job insecurity" (Thompson 2003: 373). In other words, systemic macro factors outlined above directly translate into a more precarious, volatile and disengaged workplace environment, resulting in heightened job insecurity, short-term employment contracts, increasing levels of zero-hour contracts and increased performance monitoring (Rubery et al. 2016). 
It would seem plausible that the level or effectiveness of "employee voice", itself an important aspect of "job quality" (Gaillie 2013), might also become increasingly side-lined in this environment (Hauptmeier and Vidal 2014). Decreasing levels of employee voice would also have a knock-on effect in terms of employee motivation, trust, engagement and creative input in the workplace. Given the non-permanent, contingent nature of labour, discussed above, coupled with the attendant "workplace fissuring" (Weil 2014) presumably longer-term investments, such as developing human capital, would also be reduced. Indeed, financialisation might continue to reward value extraction rather than value creation, an important by-product being that access to capital to enable investment becomes problematic for all but the largest corporations (Appelbaum and Batt 2014).

A potential limitation of the DCT is an implied universalism, with the inference that all forms of capitalist enterprises are set on a collision course with these wider systemic forces. According to some, the tensions between minimal workplace regulation and managerial prerogative suggest a "high probability that managers may renege on bargains generated with employees even under work regimes designed for collaborative mutuality" (Dobbins and Dundon 2015: 3). Little room is left within the concept for 'agency', in the form of organisations that deviate from the -i.e. independent shareholder company- capitalist norm, which can try to withstand these volatile pressures. Protagonists of the DCT concede, however, that not all workers will be equally affected by the malign forces associated with growing insecurity and attendant workplace pressures (Findlay and Thompson, 2017). It begs the question whether there are some organisational forms, such as employee ownership, which can at least in part insulate their workers from the potential adverse effects encapsulated by the DCT? Indeed, some 
researchers claim that within this new turbulent landscape, employee ownership can offer an effective means of "saving jobs and anchoring capital in communities" by "changing workplace relations and introducing workplace relations on the basis of trust" (Wills and Lincoln 1999: 1509).

\subsection{Employee-Ownership and Management-Labour Relations}

We now examine the unique nature of employee ownership which may result in different workplace outcomes to those envisaged by the DCT. Several authors postulate that within some atypical work environments, such as employee ownership, managers may be less willing to renege on workplace bargains agreed with employees (Kruse et al. 2010; Blasi et al. 2014). Owing to their unique ownership and organisational structures many of fundamental problems within conventional firms, such as classic principal-agent issues, are reconciled.

Blair (1998), for example, illustrates how employee ownership manages to 'square this circle' by ensuring that the risk-bearers are those directly in control of the firm. Having employees who are also owners of the firm, aligns the interests of shareholders and employees in such a way that "their relationship with the organization is changed and this affects the way they think and behave" (Wagner et al. 2003: 848). Furthermore, employee opportunism is checked through screening, social conditioning and incentive instruments (Williamson, 1985). Governance systems also determine how decisions about resource allocation are made and how management and employees are evaluated, remunerated and promoted (Blair 1995). According to some researchers, a firm's employees are much more likely to be motivated to "find new ways to innovate or cut costs" if they "share in the wealth creation by these 
activities" (Blair 1995: 17). This suggests the governance structures of organisations are inextricably linked to the nature of how employees are personally incentivised and their operational outcomes and hence to the effects of DCT.

Empirical evidence suggests that EOBs can, and do, respond and behave differently to conventional investor-owned firms in a number of ways. Scholars claim interest in employee ownership stems from the fact it can stimulate workers to work harder and more effectively; produce greater employment stability and firm survival; broaden the distribution of income; and create more harmonious workplaces by aligning incentives (Kurtulus and Kruse, 2017). Explanations for higher productivity appear to hinge on the bringing together and integrating of a number of human resources policies and practices, management, leadership and organisational development (Kruse et al. 2010; Pendleton and Robinson 2010; O'Boyle et al. 2017). In particular, their focus on so-called "high commitment" models such as high performance work systems (Appelbaum 2000) is in stark contrast to traditional "ones based on control and compliance" (Thompson 2011: 358). Under this model employees are generally much more engaged in the firm's activities by thinking and acting like "owners" (Wagner et al. 2003).

One critical distinction differentiating EOBs from traditional firms is the greater levels of job security it instils within employees. Security of employment seems to be the primary "tie that binds" workers to worker-owned organisations (Heras-Saizarbitoria 2014). Research strongly shows that these businesses are also associated with sustainable long-term growth, especially in terms of continuity of employment (Kurtulus and Kruse, 2017). In the UK, EOBs out-perform 
non-EOBs especially in terms of employment stability during the latest recession, and researchers suggest that EOBs view their employees as their "biggest asset" (Lampel et al. 2014). Recent research in the USA similarly found that EOBs were less likely to reduce employment in the face of economic shocks (Kurtulus and Kruse 2017). In other words, these firms can weather the economic cycle more effectively than traditional firms thereby providing additional macroeconomic stability during recessionary periods. High levels of employment stability and reduced labour-management conflict also contribute to the improved employee "wellbeing" within these firms. Job insecurity, in particular, can have direct links to wellbeing at work and research suggests EOBs perform strongly on this measure (McQuaid et al. 2012) ${ }^{7}$. An additional knock-on effect of employee ownership is the ability of employers to retain staff for instance through greater psychological commitment by employees (McConville et al. 2016; Rousseau and Shperling 2003; Pendleton et al. 1998). A recent comparative study found EOBs to have lower workforce turnover, with positive benefits in terms of productivity (Basterretxea and Storey, 2017). Higher wages also linked to employee ownership, which is thought to contribute to "the construction of a trust culture inside firms" (Baghdadi et al. 2013: 15). Overall, most studies have highlighted both extrinsic motivational factors, such as higher wages, which derive from employee ownership (Klein 1987), and intrinsic motivation, such as recognition, security and fair treatment within the context of employee-owned firms, as factors driving organisational commitment and performance (Kuvaas 2003). While some of the

\footnotetext{
${ }^{7}$ Employee ownership seems to produce higher rankings on a range of wellbeing measures such as job satisfaction, job security and sense of achievement (see McQuaid et al. 2012).
} 
evidence is mixed, the majority of studies suggest that under employee ownership firms seem to operate and function differently to conventional capitalist firms.

Naturally, the literature has limitations: it is under-theorised (Caramelli 2011) and dominated by quantitative studies. Arguably, more qualitative methods are needed to help unravel the intricacies of how these firms operate, especially in difficult recessionary periods (Kurtulus and Kruse 2017). While attempting to help overcome some of these omissions the main aim of this paper is somewhat bolder. This study undertakes a novel theoretically informed qualitative analysis of management-labour relations within (mostly small) firms either in, or transitioning to, employee-ownership. Given the hypothesised effects of disconnected capitalism highlighted above - namely increased insecurity of employment, declining employee participation, increased levels of performance measurement and reduced levels of employee well-being - it is important to examine whether these behavioural and organisational factors are equally prevalent across EOBs. Therefore, the major innovation of this paper is its attempt to widen the focus of previous studies to assess whether employee ownership provides a full or partial resolution to apparent key contradictions inherent within contemporary capitalism. In other words, can employee ownership insulate firms from the dysfunctional elements of contemporary capitalism depicted by the DCT?

\section{Methods}

\subsection{Definitions and Method}

Employee ownership encompasses a broad array of practices. Unfortunately, different variants of employee ownership are often used interchangeably despite considerable heterogeneity 
across organisational forms (Kruse et al. 2010; O’Boyle et al. 2016). Given these definitional ambiguities, care was taken to ensure the same types of firms were examined during the study. Pendleton (2011: 315) distinguishes firms with financial participation using a threefold taxonomy: worker cooperatives; firms with minority share plans; and "firms that are substantially or wholly worked owned". The firms examined in this sample all fell into the latter category, including having a heightened level of employee voice. All the firms examined adopted these forms of ownership and organisational structures.

The study was based on ten in-depth case studies of Scottish EOBs ${ }^{8}$, an effective method for exploring complex multi-causal empirical phenomena (Eisenhardt 1989). Interviews were the primary method used to construct the case studies as they are suitable for exploring the complex issues shaping management-employee relations and employee 'voice'. Semistructured interviews with open-ended questions were conducted, enabling unprompted issues arising from interviewees to be delved into more deeply. The types of questions covered during the interviews probed into the nature of the transition to employee ownership; employee participation levels; job security; employee autonomy, engagement and creative input; organisational performance issues and financial impediments to effective performance. Particular focus was paid to the cognitive behaviours and mind-set of employees and managers in relation to issues pertaining to the DCT such as workplace relations, feelings of job security and workforce engagement. To prevent "organisational silence" anonymity was guaranteed to

\footnotetext{
${ }^{8}$ While a relatively small sample size, this does nonetheless represent around a sixth of all EOBs in Scotland at the time of the study (see CDS 2012).
} 
interviewees, but unlike other recent studies on worker owned businesses the interviews took place within the workplace context (Heras-Saizarbitoria 2014).

From the total population of 86 employee-owned firms based in Scotland, fifteen EOBs were contacted using a database provided by Cooperative Development Scotland (CDS). Five declined to participate in the research leaving a sample of 10 firms. All the firms had their headquarters in Scotland. Past research examining employee ownership has often tended to overlook "employees" (Poutsma et al. 2012: 1514). To address this anomaly, the research elicited the views from both managers and employees within the same firms to help triangulate the different management-labour perspectives. Two people from each of the ten firms - one manager and one employee - were interviewed $(n=20)$. All the employees interviewed were, or had been, employee representatives. The interviews were mainly conducted face-to-face $(n=15)$ with the remainder (based in remote areas or where participants requested) by telephone. On average, the interviews lasted between 30-60 minutes and were audio recorded with the interviewees' permission. All interviews were transcribed verbatim.

In order to triangulate the veracity of the data from the firm-specific interviews, a range of other stakeholders were also interviewed such as business support managers from CDS, policy makers and other organisations (Employee Ownership Association, specialist funders and lawyers, banks) to examine more general issues in relation to the situation within firms adopting employee ownership, resulting in a further 14 interviews. In total the research involved 34 interviews, a figure above the norm for workplace studies (Saunders and Townsend 2016). 


\subsection{Data Analysis}

The resulting transcriptions of interviews were analysed using a partially grounded analysis (Charmez 2014). They were analysed in the manner outlined by Easterby-Smith et al. (2015) for whom grounded analysis tends to be holistic as it aims to derive structure from data by comparing different data fragments with one another. Several members of the research team undertook the preliminary data coding process (data familiarisation, reflection and opencoding). Discussions between co-authors were an important part of the coding process. At this stage codes were keep simple to enable the researchers to remain close to the data (Charmaz 2014). Following this, the researchers undertook the second order conceptualisation which included focused re-coding, linking and re-evaluation. This method allowed for the identification of several key themes informed by the research objectives (such as workplace engagement, employment security, employee engagement and creativity), which were entered into a matrix to allow comparability of issues across interviews. Once the initial coding took place formal case studies were constructed for each case.

\subsection{Firm Characteristics}

Cumulatively, the ten firms employed approximately 2,750 people in 2012, representing just over half of the overall employment within Scottish EOBs. The majority were SMEs employing considerably less than 249 employees, except one who had a turnover of over $£ 150$ (\$200) million and around 700 employees (see Table 1). A key feature of the cohort was their considerable heterogeneity. The diverse sectoral and spatial composition of EOBs was reflected 
in the sample with a range of activities such as residential care homes, publishing and high-tech manufacturing and a wide geographic coverage of the firms across the whole of Scotland.

[Insert Table 1 about here]

The firms were also quite disparate in terms of age with the majority established during the last twenty to thirty years, but three firms were significantly older. An interesting feature of the majority of these firms' was their previous ownership status - the majority were previously family-owned firms and only one of the participating businesses had been employee owned since its inception. Employee ownership was relatively new to most of the firms with five being employee owned for less than three years, three being employee owned for 8 years, 18 years and 35 years respectively and with two still in the process of transition towards employee ownership 9 .

In terms of their performance, less variation was discernible. The participating EOBs supplied around 5 years annual data on turnover, number of employees; pre-tax profit, percentage profit margin and return on capital employed. The main indicators of performance examined were employment and turnover growth. With the exception of firm D, all the firms in the sample had been experiencing relatively strong employment and turnover growth over recent years. Financial data from the FAME business database was used to compare the performance of the participating firms against a selection of non-EOB counterparts ${ }^{10}$. The peer group was selected from companies in the same sector and similar size brackets. Paired t-tests were used

\footnotetext{
${ }^{9}$ While in the transitional process these firms have adopted the workplace practices associated with employee ownership status.

${ }^{10}$ The findings from this element of the study are reported elsewhere (reference to be inserted after refereeing).
} 
to ascertain if the differences between EOBs were significantly higher than their peers (5\% significance levels). This found that the performance of these Scottish EOBs was generally superior to their peers in terms of growth (consistent with many other studies cited above). Overall, Scottish EOBs appear to have, on the whole, higher turnover, employee growth, higher profitability and greater return on capital than their non-EOB counterparts. The only area where they performed less well was on average salaries which may owe to the frequent use of profit-related bonus schemes within these firms and to the value given to retaining profits for investment.

\section{Empirical Findings}

The findings below report the responses of both management and employees within these EOBs in relation to the potential negative aspects associated the DCT. To unpack whether these firms can withstand the pressures endemic with DCT we examine workplace participation, job security within EOBs, employee autonomy, engagement, creativity and the impact on their financial affairs.

\subsection{Workplace Participation}

The DCT predicts that workplace participation and employee engagement will be largely absent in firms. Therefore, we would expect to see minimal levels of workplace participation and employee engagement within the cohort of interviewed firms. Contrary to these expectations the EOB workplaces examined seem to display strong levels of workplace participation and high levels of employee engagement. Pathways into employee ownership are often complex and the cohort of firms clearly represents a complex picture of their evolution towards employee 
ownership status. A number of managers and employees noted the developing nature of employee participation and workplace culture and the need to move towards more participative management styles.

"One of the biggest problems we have had, and still have, but hope to cure, is the 'us and them' one. And I can understand that because the previous owner gave out no news. He never gave out bad news; he never gave out good news. He made his decisions....that always builds up a mistrust, so we have a job in changing that" (Director)

From the employee side, in terms of formal participation mechanisms, employee representatives were in the vast majority of cases $(n, 8)$ elected for a term (often three years) on the Board to contribute employee views. For these employees, discussing issues directly affecting their colleagues, and being open with senior staff members, could be a challenging and evolving process.

"The first time you go up it's really quite a daunting thing to talk to the head of the company; but after 5 or 6 meetings it becomes a lot easier and a lot more open and honest, because you can ask a question without a fear of losing your job I suppose" (Employee)

Regular general meetings were also held in some of the companies, which enabled employees to ask questions and have open discussions with management about performance and financial issues, a process uncommon in traditional UK SMEs. According to one employee: "they don't hold back about money situations, everything is talked about" 
(Employee). These sessions were perceived positively and the communication of financial performance issues or 'open-book' accounting was the key to the process of employee ownership for many ${ }^{11}$. The managers also cited the value of the contributions made by employee representatives at these meetings.

"The biggest change for me as a decision-maker is the significant contributions I get from the other groups and it's just so much better to have six opinions than two" (Director)

This suggests the move to employee participation entailed firms becoming more inclusive and open, with employees having a greater influence over decisions; although this influence can still be limited in certain respects. For instance, one employee highlighted that increased employee awareness of the position of the business was not always positive and could increase anxiety among the workforce, where previously they may not have fully grasped the negative effects of the recession. However, increased feelings of 'togetherness', because of employee ownership, could help counter these feelings. Employees also felt a greater responsibility to become involved in decision-making, which helped reduce any conflict between employees and management compared to (previous) non-EOB situations.

"Well it is actually, because especially at the moment when the economy is quite bad and you do see the sales going down. So yes it is quite stressful because it is hard to know how to pull that back (a)round...But it is nice to know that there are [all] of us in it together, it's not just on a few shoulders, it's on us all. So that is good" (Employee)

\footnotetext{
${ }^{11}$ Open book accounting in employee-owned firms is the process of making financial information both available and accessible to employees within a firm - such informational transparency often features in firms with very high levels of employee participation (Timming and Brown 2015).
} 
"By not listening to the employees, that's when things start to have a bit of a conflict and it prevents people from all having one focused goal and all working towards one goal" (Employee)

While employee ownership was accompanied by a move to ownership-centred voice, power-centred forms of voice did remain in some cases, such as the emphasis on the continued role of directors as the final decision makers.

"At the end of the day somebody has to be the one who has to carry the can for making a decision whether there is a deadlock or gridlock; but I think we are quite responsive and inclusive in the way that is operated. So people know the buck stops somewhere. Sometimes then they're quite comfortable with that as long as it has been explained to them, as long as there is a rationale there they can understand" (Director)

\subsection{Employment Security}

Endemic problems of job insecurity are strongly depicted within the DCT. Therefore, we would anticipate concerns and uncertainty around continuity of employment to be prevalent among firm employees. Despite this, high levels of employment security seemed to be a recurring feature permeating throughout the organisations studied, although this security was subject to wider sectoral and cyclical pressures. As noted above, over half of the sample (seven firms) had recently become employee-owned. Owing to this it was difficult to fully assess how their growth performance had altered pre- and post-employee ownership. Another complicating factor was that for many of the firms this transition had occurred during the recent global 
financial crisis. Clearly, disentangling the impact of endogenous organisational changes versus exogenous factors such as macroeconomic conditions is problematic.

Interestingly, however, the majority of firms found that the recession "hasn't been that significant" (Director). Despite these issues, the overall sense from these nascent 'convertors' to EOBs was that the transition had improved their effectiveness. As one Director claimed: 'I don't think it would have grown as quickly as we have if we hadn't gone down the employee ownership route' (Director)

Identifying the precise reasons why employee ownership had led to superior economic performance uncovered a complex, multi-causal series of contributory factors. It was observed by many employees within EOBs that being a shareholder in the business made them more committed and productive workers. As one employee noted:

"I think we do try quite a bit harder to make sure that what we do during the course of the day is important and I think we're all working much, much harder. Yeah, because we do feel a responsibility" (Employee)

The attachment of employees to the firm, or organizational commitment, is one explanation for this 'normative commitment'. What seemed crucial to many workers was that the feeling of job security gave workers extra incentives and commitment to their employer. Feelings of greater security of employment seemed to be the primary benefit from this model of ownership across the employee interviewees. This seemed particularly important given the potential impact of the recession on the businesses interviewed. 
"It's just not about the financial rewards. It's good but it's more about the job security. From that point of view...all the guys understand that the efforts they put in, not just a financial gain but also a long term employment gain and the success of the company; it's securing your future" (Employee)

"It has been a struggle but we haven't just turned around and laid people off, we've tried to get through any problems that we have got, not by losing staff, but by cost saving across the business" (Employee)

An additional consequence of their status as part 'owners' was that staff engagement, and motivation were seen as high and directors and employees both noticed commensurately higher levels of commitment from employees with both financial rewards and perceived job security playing a part. Managers also viewed staff motivation and engagement as important drivers of productivity, especially given the tough economic conditions confronting the businesses.

"We do an annual engagement survey and you know we have certainly seen a significant increase in both engagement and the level of satisfaction over the last 3 or 4 years despite the economic conditions. So I think that is hugely encouraging for us and again I think it is a testament to our employee ownership" (Director)

\subsection{Employee Autonomy, Engagement and Creativity}

At the core of the DCT is a lack of employee engagement which manifests itself in a lack of autonomy and creativity. Typically, low levels of employee autonomy, high levels of 
performance measurement, limited employee engagement coupled with low levels of employee creativity would all feature strongly. None of these features were evident within the firms interviewed. Many of the firms delegated considerable autonomy to employees and none had any strong form of performance measurement frameworks in place. In turn, this appeared to generate more employee autonomy and stronger engagement in the firm.

A further aspect of employee engagement was the knock-on effect in terms of their relationships with other employees. This relational impact resulted in viewing the 'entire' organisation more favourably than in traditionally structured companies. This seemed to result in employees working 'harder' and 'smarter', although as discussed above the motive seemed partly based on wider responsibility. The influence of employee ownership based organisational identification on the individual, and the wider impacts of this, was encapsulated by both management and labour:

"I think it comes back to leadership and motivation. If you have got an employee owner and you say to them 'look we need to double our output', then they know it benefits the company and it benefits them because as a shareholder they enjoy the growth in capital.... You know, for me, that is at the heart of employee ownership because it really means that everyone is in it together and everyone will share in the success of that" (Director)

"I think because you feel more of a 'family' of people because we're all trying to work together. I think we are very committed and I think we are more committed that most companies" (Employee) 
In addition to working harder, employee-ownership in the businesses studied often resulted in employees working 'smarter' and more creatively, especially in terms of initiating innovative activities and problem solving. This appeared to be the case in the overwhelming majority of the businesses, irrespective of size or sector, and was corroborated by both management and employees alike. This sometimes took the form of proactively promoting new innovative initiatives within companies. For example, in one company the employees initiated a workshop type event with a key customer to help better customise their products to their specific requirements. It could also take a more indirect form, by employees voicing "shop-floor" concerns about the feasibility of various new product-related concepts proposed by management. Nearly all the companies utilised regular 'open forums' to explore operational issues and how identified difficulties could be resolved. These are often critical for harnessing a supportive culture of adaptation and experimentation.

In other words there is an inclusive approach towards innovation which resulted in "more ideas coming from different parts of the organisation" (Director). This engagement in turn has a clear impact in terms of firm performance by enabling an environment where "people have the guts to branch out and take some risks and in doing that have brought in more business" (Employee). In a similar vein, employee ownership also improved productivity by encouraging a stronger focus on "upward problem solving". This is typically linked to enhancements around process innovation as well as incremental improvements. Again, across the companies interviewed the vast majority noted how employees often showed their creativity and autonomy by tackling problems directly at source rather than referring them upwards to management. While 
beneficial for productivity, managers also noted the benefit this yields for management. One Director noted how greater employee autonomy and responsibility, compared to before employee ownership resulted in increased productivity:

"You see higher levels of engagement. We see problems being solved at source rather than being passed up through the management line to arrive on the desks of the frazzled few. So first responder to solutions, meaning that cost of production fall and productivity rises" (Director)

Being viewed as contributors to the way the business operates clearly resulted in workers feeling more committed to their employer. Also, higher levels of autonomy within EOBs appeared to result in greater creativity and levels of delegated authority within the firms. Rather than a mechanism for cost minimisation, greater autonomy within the workforce can help identify positive spillovers in revenue growth in terms of suggestions to customise or amend their products and services. Both management and employees in one recently converted EOB made similar claims:

"For the people who own shares, since we started doing this we have seen quite a difference in terms of people's creativity and innovation etcetera and also seeming to want to go that little bit further" (Director)

"There doesn't seem to be as many barriers for ideas for improvements and everybody seems to be a lot more proactive and everyone is a lot more enthusiastic and wants the company to do well. They're not just coming into work and just doing the job and going home, everyone is trying to do the best job they can" (Employee) 
Another key factor which seemed to engender organisational efficacy is the impact of employee ownership on recruitment and human capital development within firms. In particular organisational commitment and identification seemed important for productivity enhancement. Greater levels of perceived job security offered by EOBs augmented the commitment of workers. Firms also appeared to view employee ownership as a means of differentiation in the labour market. A number of interviewees stated that being employeeowned conferred a special status on firms, enabling them to recruit and retain good staff.

"So we see a growing appetite for training and development, we see people not leaving and we see interesting applicants wanting to join the organisation" (Director)

"I think we have a pretty loyal staff base here. We don't tend to turnover staff that much which is unusual for [the sector]. [The sector] tend[s] to turnover people pretty quickly. It's a sort of kind of a joke in our business that people come here for a few months and then stay here for...years" (Director)

One company maintained that a key advantage for firms was the relationships staff had developed with customers. Relatively low levels of staff turnover compared to their peers further augmented the strong customer focus within these businesses:

"Customers like dealing with employee owned companies because, I think, there's a stability about employee owned companies which customers like and the commitment from everybody at the organisation and so we're looking to exploit that as an employee owned company" (Director) 


\subsection{Financialisation and Inclusive Decision Making}

Financialisation, and the need for cost savings and performance measures, have been an important element driving the DCT. Within the DCT one would expect financialisation to increase financial constrictions on firms and reduced employee involvement in financial decision making. In this respect, the findings are somewhat inconclusive. While some encountered difficulties in their dealings with banks resulting in more modest levels of growth, perhaps linked to servicing the loans for taking ownership of the firm, others faced less difficulties ${ }^{12}$. Overall, employees appear strongly involved in major strategic financial decisions and this inclusive approach to financial affairs often meant decisions occurred more slowly within these firms.

The issue of funding did seem to resonate particularly strongly with some of the firms. While not universal, the majority of firms reported difficulties with their primary lenders which impacted upon their businesses. The inference was that banks did not fully understand the nature of employee ownership and that this lack of knowledge penalised them. Indeed, in one instance the change into employee ownership precipitated the bank to withdraw their overdraft facility. This can have significant ramifications for some, but not all, EOBs:

"We had no overdraft at all, they pulled the plug. They wouldn't support the change of ownership. So, huge barriers" (Director)

\footnotetext{
12 The researchers were not able to directly ascertain the extent to which servicing loans to fund the transferal of ownership affected their ability (or desire) to seek external sources of finance.
} 
"We've experienced no barriers - we have raised finance, albeit hire purchase finance...the banks are all too keen to deal with us...because we're borrowing more than $£ 50,000$ we had to put it out for approval for employee owners" (Director)

While this disruption was rare in our sample, for those who had recently transitioned into employee ownership there seemed to be other consequences of funders' lack of knowledge. For some this resulted in a "more patient attitude towards growth" (Director) being undertaken by the firms. This more cautious approach towards business growth engendered greater self-sufficiency in terms of financial resources. The use of retained profits to fund the expansion of these businesses was a core strategy deployed to counter limitations of credit availability. Owing to the strong profitability of some firms this was not seen as problematic, but for others it was seen as a considerable barrier to growth.

"For us finance is a big, big challenge. We don't have investors; we don't have huge amounts of capital. You know we don't have millions of pounds sitting in the bank waiting to absorb some sort of mistake that we might make... we don't have any flexibility or movement to make mistakes so we have to move carefully, we have to move slowly, we have to expand our business within the confines of what we can finance ourselves or we can get small amounts of lending from the bank" (Director)

Another crucial knock-on effect of employee ownership on organisational behaviour concerned the inclusive decision-making process within firms. Most of the firms highlighted that being employee-owned entailed much slower financial decision making processes. This was mainly because employees had to be consulted prior to any major strategic capital 
investment decisions being made. In some instances this was felt to have a detrimental effect which stifled organisational responsiveness: "even when people have a bright idea...it can be very slow" (Director). Highlighting the negotiated nature of this process, one Director remarked:

"I liken our business to a glacier, we are very powerful when we do move but we move incredibly slowly because we have always got to be checking and making sure that what we're doing is the right thing for our membership. I would say that that can be a good thing in most cases, but can also be a bit of a challenge" (Director)

\section{Discussion}

The research examined whether employee-ownership could shield and mitigate against various micro-level issues associated with the DCT, such as the overall quality of employment within contemporary workplaces, such as workplace participation, employment security, employee autonomy, engagement/creativity and the effect of financialisation on decision making. It analysed the issues within the context of a sample of Scottish EOBs to ascertain if these organisations have been able to withstand the deleterious effects associated within the DCT. Our findings are clear: employee ownership does appear to insulate firms and workers to some degree from the dysfunctional elements of contemporary capitalism. As others have found, employee involvement in corporate governance seems to play a crucial role in underpinning a firm's resilience, especially during adverse economic conditions (Lampel et al. 2014; Kurtulus and Kruse 2017). 
It should be noted that these perceptions of greater workplace inclusion and employment security are far from uniform across the cohort examined. The study found that entering into employee ownership is a complex and evolving process for both management and employees. In more recently converted EOBs, feelings of "role ambiguity" may somewhat impinge on these feelings of resilience. If employees do not know what authority they have and how they will be judged they will hesitate to make decisions (Rizzo et al. 1970). Likewise, managers have to adapt to these new organisational forms by adopting a more modest approach to growth due to limitations on external finance. This suggests that employee ownership is a form of "learned behaviour" for the actors involved rather than something automatically engendered by incorporating this alternative form of ownership structure ${ }^{13}$.

In terms of workplace participation, the research found - and corroborated by both managers and employees alike - that inclusiveness and strong levels of workplace participation were prevalent features within these organisations. As anticipated within the DCT, employment insecurity is predicted to be endemic (Thompson 2013). By contrast, a central finding here was the importance attached to job security as a primary benefit arising from employee ownership. This finding corroborates other recent research (Heras-Saizarbitoria 2014; Kurtulus and Kruse 2017) showing that a fundamental advantage of employee ownership is the ability of these firms to offer added levels of employment stability. This in turn seems to have positive spillovers in terms of the overall workplace culture within these firms such as relatively high levels of trust, strong employee engagement and high levels of employee commitment coupled

\footnotetext{
${ }^{13}$ The authors are grateful to one of the referees for prompting the authors to consider this differentiated process across the firms converting to employee ownership.
} 
with high levels of employee creativity. Therefore, the primary beneficial factors engendered by employee ownership are these combinative cognitive factors which translate into feelings of inclusion and ownership within the workforce which can act as a bulwark against the expectations embedded -especially around job insecurity and alienation- within the DCT.

Endorsing other recent evidence (Harden et al. 2010), owing to high levels of personal delegation, autonomy and empowerment, another key finding was the role employeeownership played in fostering the creativity and innovation. Once again, this finding goes against the kind of employee detachment hypothesis predicted by the DCT. Effective performance in employee-owned firms is not simply a function of employees working 'harder' but employees working 'smarter', in line with the notion of 'upward problem solving' within workplaces identified by others (Marchington 2005). While traditionally upward problem solving is associated with the identification of cost savings (i.e. process innovation), this study found that the synergies from a participative workplace can also augment the innovative capabilities (i.e. product innovation) of the firm (in line with Blair 1995); especially through increased pro-social behaviour and engagement with other employees and customers. It seems a reasonable assumption that employees in the majority of typical firms would not display these participatory and pro-social behavioural characteristics harnessing employee creativity. Central to the concept of DCT is the malign effects of financialisation for workplace relations (Thompson 2013). From this evidence, the impact of financialisation on EOBs seems to have produced mixed effects. In terms of their ability to obtain capital for growth during the aftermath of the global financial crisis, for some firms there was little discernible impact. 
However some managers viewed their ownership structure negatively as banks appeared to reduce their ability to obtain external finance and slowed down decision making in the firms. On the other hand, the majority of employee respondents felt the benefits of their inclusiveness and patient decision making outweighed any drawbacks. This slower approach towards financial decision may result in more long-term strategic planning in these firms.

Differing perceptions of financialisation allude to wider, quite subtle, cognitive distinctions between management and employees within the same firms (see Table 2 below). For managers the importance of direct financial participation is viewed as the key motivational driver and the basis of a strong perceived work ethos within employees. For employees, on the other hand, financial incentives were less immediately important whereas feelings of responsibility and commitment to the organisation increased in importance. Given the impact of the recession, the key motivation for most employees was job security and commitment rather than any perceived financial gain resulting from being a shareholder in firms. In other words, intrinsic factors seemed to be a key motivational driver for workers (Pendleton et al. 1998; Levine 1990; Wagner et al. 2003), rather than the extrinsic motivators assumed by managers. This differentiated perspective points to the need to better comprehend the variable and negotiated cognitive factors underpinning employee ownership.

[Insert Table 2 about here]

\section{Conclusions}

This study makes a number of important contributions to the literature on employee ownership and disconnected capitalism respectively. Contrary to the expectations embedded within the 
DCT there does not appear to be a single or 'inevitable' workplace outcome emanating from these powerful forces. In other words, employee owned workplaces are different. By adopting a theoretically-informed inductive case study approach the research yielded important new empirical insights on this growing organisational phenomenon. It reveals a series of complex causal processes underpinning their relatively strong performance and inclusive workplace practices which supports the perpetuation of a virtuous cycle of high commitment and high productivity. It appears the "safety net" of secure employment is a crucial ingredient underpinning the positive cognitive and relational processes embedded within these organisations.

All this suggests a powerful role should be ascribed to the cognitive aspects of ownership within organisations. Employee ownership engenders a relational bond between employees and firms, enabling a form of "connected capitalism". ${ }^{14}$ Within these atypical employment environments - in contrast to the DCT - employees feel strongly connected and committed to their employer, with resultant benefits particularly in terms of employee engagement, greater levels of employee creativity and, ultimately, enhanced productivity gains.

Of course, employee ownership is no organisational panacea. These firms are far from immune from the wider systemic forces, including financialisation, within the global economy that may reduce job security and other benefits perceived by employees over time. Adapting to employee ownership seems to be temporally mediated as new behaviours and attitudes take time to become organisationally and culturally embedded. Additionally, there are clearly

\footnotetext{
14 There is a strong undercurrent of "ownership" within the aforementioned film on employee ownership exemplified by the following quotation: "I treat my job like it's my own business" (Michael Miller, New Belgium Brewing Company, quoted in 'We the Owners', 2013).
} 
different sides to the story of employee ownership which have been largely overlooked in previous research. Clearly, turning workers into 'capitalists' does not, by itself, completely change the "capital-labour relationship" (see Cathcart 2014).

From a theoretical perspective, these findings suggest that considerable care is needed when translating employment trends into overarching theoretical constructs such as the DCT. The manner in which disconnected capitalism takes hold and mediates organisational behaviour is far from uniform. Therefore, further theoretical refinement is needed to examine the generalisability, applicability and durability of this concept. Exploring the variegated nature of the DCT across different organisational forms could potentially yield valuable additional explanatory insights into the nature of contemporary capitalism.

Inevitably, there are limitations with this kind of inductive research in terms of its wider generalisability. Given the fluidity of changes inherent within contemporary workplaces, further work is clearly needed using different research methods, geographical contexts and theoretical perspectives to closely scrutinise whether firms within employee ownership can continue to "keep their side of the bargain" given the magnitude of the powerful forces (re)shaping the turbulent post-Fordist era.

\section{References}

Appelbaum, E. (Ed.) (2000). Manufacturing advantage: Why high-performance work systems pay off. Ithica, NY: Cornell University Press.

Appelbaum, E., \& Batt, R. (2014). Private equity at work: When wall street manages main street. New York: Russell Sage Foundation. 
Baghdadi, L., Bellakhal, R., and Diaye, M. A. (2013). Financial Participation: Does the Risk Transfer Story Hold in France? British Journal of Industrial Relations, 54: 3-29.

Basterretxea, I., and Storey, J. (2017). Do Employee-Owned Firms Produce More Positive Employee Behavioural Outcomes? If Not Why Not? A British-Spanish Comparative Analysis. British Journal of Industrial Relations, doi:10.1111/bjir.12247.

Blair, M (1995). Ownership and control: Rethinking corporate governance for the twenty-first century. Brookings Institution.

Blair, M. (1998). For Whom Should Corporations Be Run? An Economic Rationale for Stakeholder Management, Long Range Planning, 31: 195-200.

Blasi J.R. Freeman R.B. and Kruse D.L. (2014). The Citizen's Share: Putting Ownership Back Into Democracy. New Haven: Yale University Press.

Blasi, J., Freeman, R., \& Kruse, D. (2016). Do Broad-based Employee Ownership, Profit Sharing and Stock Options Help the Best Firms Do Even Better?. British Journal of Industrial Relations, 54: 55-82.

Caramelli, M. (2011) 'Employee Ownership and Corporate Performance: Toward Unlocking the Black Box'. In Carberry, E. (Ed) Employee Ownership and Shared Capitalism: New Directions in Research, pp. 311-40, Labor and Employment Relations Association, Campaign, Illinois.

Cathcart, A. (2014). Paradoxes of participation: non-union workplace partnership in John Lewis. The International Journal of Human Resource Management, 25: 762-780.

Charmaz, K. (2014). Constructing grounded theory. Second Edition. London: Sage.

Christopherson, S., Martin, R., \& Pollard, J. (2013). Financialisation: roots and repercussions. Cambridge Journal of Regions, Economy and Society, 6: 351-357.

Cooperative Development Scotland (2013) The Growth of Employee Owned Business in Scotland. Report to Scottish Enterprise, Glasgow.

Croucher, R., Brookes, M., Wood, G., and Brewster, C. (2010) Context, strategy and financial participation: A comparative analysis. Human relations, 63: 835-855.

Dobbins, T., \& Dundon, T. (2015). The chimera of sustainable labour-management partnership. British Journal of Management, DOI: 10.1111/1467-8551.12128

Easterby-Smith, M., Thorpe, R., \& Jackson, P. R. (2015). Management and business research. Fifth Edition, London: Sage. 
Eisenhardt, K.M. (1989). Building theories from case study research. Academy of Management Review, 14: 532-550.

Employee Ownership Association (2014) Employee Ownership Impact Report, London. Download from: file://C:/Users/Administrator/Downloads/The-Impact-Report.pdf

Findlay, P., \& Thompson, P. (2017). Contemporary work: Its meanings and demands. Journal of Industrial Relations, 59: 122-138.

Gallie, D. (2013). Direct participation and the quality of work. Human Relations, 66:, 453-473.

Harden, E. E., Kruse, D. L., \& Blasi, J. R. (2010). Who has a better idea? Innovation, shared capitalism, and human resources policies. In Kruse D.L. Freeman R.B. and Blasi J.R. (Eds) Shared capitalism at work: Employee ownership, profit and gain sharing, and broad-based stock options (pp. 225-253). University of Chicago Press.

Hauptmeier, M., \& Vidal, M. (Eds.). (2014). Comparative political economy of work. Palgrave Macmillan.

Heras-Saizarbitoria, I. (2014). The ties that bind? Exploring the basic principles of worker-owned organizations in practice. Organization, 21: 645-665.

Jessop, B. (1995). The regulation approach, governance and post-Fordism: alternative perspectives on economic and political change?. Economy and society, 24: 307-333.

Kramer, B. (2010). Employee ownership and participation effects on outcomes in firms majority employee-owned through employee stock ownership plans in the US. Economic and Industrial Democracy, 31: 449-476.

Kruse D.L. Freeman R.B. and Blasi J.R. (2010). Shared capitalism at work: Employee ownership, profit and gain sharing, and broad-based stock options. Chicago: University of Chicago Press.

Kurtulus, F. A., \& Kruse, D. L. (2017). How Did Employee Ownership Firms Weather the Last Two Recessions?: Employee Ownership, Employment Stability, and Firm Survival: 1999-2011. Kalamazoo, MI: WE Upjohn Institute.

Kuvaas, B. (2003). Employee ownership and affective organizational commitment: employees' perceptions of fairness and their preference for company shares over cash. Scandinavian Journal of Management, 19: 193-212.

Lampel, J., Bhalla, A., and Jha, P.P. (2014). Does governance confer organisational resilience? Evidence from UK employee owned businesses. European Management Journal, 32: 66-72. 
Marchington, M. (2005). 'Employee Involvement: Patterns and Explanations'. In Participation and Democracy at Work: Essays in Honour of Harvie Ramsay, B. Harley, J. Hyman and P. Thompson (Eds). Palgrave Macmillan: Houndmills.

McCann, L. (2014). Disconnected amid the networks and chains: employee detachment from company and union after offshoring. British Journal of Industrial Relations, 52: 237-260.

McConville, D., Arnold, J., \& Smith, A. (2016). Employee share ownership, psychological ownership, and work attitudes and behaviours: A phenomenological analysis. Journal of Occupational and Organizational Psychology, 89: 634-655.

McQuaid, R., Hollywood, E., Bond, S., Canduela, J., Richard, A., \& Blackledge, G. (2012). Health and Wellbeing of Employees in Employee Owned Businesses. Employment Research Institute: Edinburgh Napier University.

O'Boyle, E. H., Patel, P. C., \& Gonzalez-Mulé, E. (2016). Employee ownership and firm performance: a meta-analysis. Human Resource Management Journal.DOI: 10.1111/17488583.12115

ONS (2017) People in employment on a zero-hours contract: Mar 2017. London: Office for National Statistics.

Pendleton, A. (2011). Employee ownership in Britain: diverse forms, diverse antecedents. In Carberry, E. (Ed) Employee Ownership and Shared Capitalism: New Directions in Research, pp. 311-40, Labor and Employment Relations Association, Campaign, Illinois.

Pendleton, A., Wilson, N., and Wright, M. (1998). The perception and effects of share ownership: empirical evidence from employee buy-outs. British Journal of Industrial Relations, 36: 99-123.

Pendleton A. and Robinson A. (2010). Employee stock ownership, involvement, and productivity: An interaction-based approach. Industrial and Labor Relations Review, 64: 3-29.

Pendleton, A. and Robinson, A. (2011). Employee share ownership and human capital development: complementarity in theory and practice. Economic and Industrial Democracy 32: 439-457.

Pendleton, A., \& Poutsma, E. (2012). Financial participation. In Brewster, C. and Mayrhofer, W. (Eds), Handbook of research on comparative human resource management, pp. 345-368. Cheltenham: Edward Elgar.

Poutsma, E., Blasi, J.R., and Kruse, D.L. (2012). Employee share ownership and profit sharing in different institutional contexts. The International Journal of Human Resource Management, 23: 1513-1518. 
Richter, A., and Schrader, S. (2016). Levels of Employee Share Ownership and the Performance of Listed Companies in Europe. British Journal of Industrial Relations, Published online first DOI: 10.1111/bjir.12169

Rizzo, J. R., House, R. J., \& Lirtzman, S. I. (1970). Role conflict and ambiguity in complex organizations. Administrative Science Quarterly, 15:150-163.

Rousseau, D. M., and Shperling, Z. (2003). Pieces of the action: Ownership and the changing employment relationship. Academy of Management Review, 28: 553-570.

Rubery, J., Keizer, A., \& Grimshaw, D. (2016). Flexibility bites back: the multiple and hidden costs of flexible employment policies. Human Resource Management Journal, 26: 235-251.

Russell, R. (1985). Employee ownership and internal governance. Journal of Economic Behavior \& Organization, 6: 217-241.

Saunders, M. N., \& Townsend, K. (2016). Reporting and Justifying the Number of Interview Participants in Organization and Workplace Research. British Journal of Management DOI: 10.1111/1467-8551.12182.

Stiglitz, J. E. (2015). The great divide: unequal societies and what we can do about them. New York: W.W. Norton \& Company

Storey, J., \& Salaman, G. (2017). Employee ownership and the drive to do business responsibly: a study of the John Lewis Partnership. Oxford Review of Economic Policy, 33: 339-354.

Timming, A. R., \& Brown, R. (2015). Employee Voice through Open-Book Accounting: The Benefits of Informational Transparency. Social and Environmental Accountability Journal, 35: 86-95.

Thomson P. (2003). Disconnected capitalism: or why employers can't keep their side of the Bargain, Work, Employment and Society, 17: 359-378.

Thompson, P. (2013). Financialization and the workplace: extending and applying the disconnected capitalism thesis. Work, Employment \& Society, 27: 472-488.

Wagner, S. H., Parker, C. P., \& Christiansen, N. D. (2003). Employees that think and act like owners: Effects of ownership beliefs and behaviors on organizational effectiveness. Personnel Psychology, 56: 847-871.

Weil, D. (2014). The fissured workplace. Harvard University Press. 
Wilkinson, A., Dundon, T., Donaghey, J., and Townsend, K. (2014). Partnership, collaboration and mutual gains: evaluating context, interests and legitimacy. The International Journal of Human Resource Management, 25: 737-747.

Wills, J., and Lincoln, A. (1999). Filling the vacuum in new management practice? Lessons from US employee-owned firms. Environment and Planning A, 31: 1497-1512.

Wright, P.M., and Snell, S.A. (1998). Toward a unifying framework for exploring fit and flexibility in strategic human resource management. Academy of Management Review, 23: 756-772. 
Table 1: Characteristics of Case Study Firms

\begin{tabular}{|c|c|c|c|c|}
\hline Company & Sector & $\begin{array}{l}\text { Date } \\
\text { established }\end{array}$ & $\begin{array}{l}\text { Number of employees in } \\
2012 \text { (rounded) }\end{array}$ & Turnover in 2012 (fm)* \\
\hline A & $\begin{array}{l}\text { Information and } \\
\text { communication }\end{array}$ & 1972 & 15 & $0.5 \mathrm{~m}$ \\
\hline B & Manufacturing & 1994 & 40 & $11.8 \mathrm{~m}$ \\
\hline $\mathrm{C}$ & Care Industry & 1994 & 250 & $4.15 \mathrm{~m}$ \\
\hline $\mathrm{D}$ & Manufacturing & 1809 & $690 *$ & $166 m$ \\
\hline$E$ & Retail & 1977 & 160 & $11.5 \mathrm{~m}$ \\
\hline $\mathrm{F}$ & Manufacturing & 1970 & 150 & $8 m$ \\
\hline G & Food Processing & 2008 & 110 & $29 m$ \\
\hline $\mathrm{H}$ & Professional Services & 2009 & 20 & $1.5 \mathrm{~m}$ \\
\hline 1 & Manufacturing & 1878 & 30 & $5 \mathrm{~m}$ \\
\hline J & Primary & 1967 & 130 & $46 m$ \\
\hline
\end{tabular}

Source: Interviews/published company sources.

*including some located overseas 
Table 2: Perceived Benefits of Employee Ownership

\begin{tabular}{|c|c|c|}
\hline Thematic Issues & Employees & Managers \\
\hline $\begin{array}{l}\text { Transitions to Employee } \\
\text { Ownership }\end{array}$ & $\begin{array}{l}\text { Fear of the unknown i.e. "role } \\
\text { ambiguity"; feelings of uncertainty } \\
\text { and 'anxiety' about the financial } \\
\text { health of the business }\end{array}$ & $\begin{array}{l}\text { Breaking feelings of "them and } \\
\text { us" between management and } \\
\text { workers }\end{array}$ \\
\hline $\begin{array}{l}\text { Changes to Workplace } \\
\text { Culture }\end{array}$ & $\begin{array}{l}\text { Increased feelings of togetherness - } \\
\text { "all in it together" - translated into a } \\
\text { more inclusive work environment }\end{array}$ & $\begin{array}{l}\text { Getting more input into } \\
\text { decision-making to enhance } \\
\text { organisational "performance" } \\
\text { and make better (although } \\
\text { slower) decisions }\end{array}$ \\
\hline $\begin{array}{l}\text { Factors Contributing to } \\
\text { Organisational } \\
\text { Performance }\end{array}$ & $\begin{array}{l}\text { Job security - "not about the } \\
\text { financial rewards....it's more about } \\
\text { job security" } \\
\text { Perceived responsibility - "it's } \\
\text { securing your future"- to work } \\
\text { 'harder' due to greater levels of } \\
\text { commitment to the firm } \\
\text { Slow financial decision making was } \\
\text { seen as a positive rather than a } \\
\text { negative which could 'guard against } \\
\text { doing rash things' }\end{array}$ & $\begin{array}{l}\text { Due to their incentivisation, } \\
\text { employees work harder 'to } \\
\text { enjoy the growth in capital'. } \\
\text { Employees deemed to work } \\
\text { 'smarter' and more creatively in } \\
\text { terms of more upward problem } \\
\text { solving }\end{array}$ \\
\hline
\end{tabular}


